\title{
Quality Perception of the 2012 World Indoor Athletics Championships
}

\author{
by \\ Kerem Yildirim Simsek ${ }^{1}$
}

The objective of this study was to compare the views of spectators concerning the quality perception of the World Indoor Athletics Championships. The study group consisted of 568 spectators who watched the events. A measurement scale of event quality in spectator sports (SEQSS) developed by Ko et al. (2011) was used as a data collection tool in the study. In order to determine the views of the spectators concerning the quality of the Indoor Athletics Championships, the dimensions constituting the scale were compared according to the demographic features of the sample group. As a consequence, important differences in most of the dimensions of the scale were revealed with respect to the demographic data of the subjects. The most relevant finding of the study is that the dimension of "physical environment quality", which is one of the dimensions constituting the event quality, differed significantly in all comparisons that were made according to demographic features.

Key words: event quality, spectator, service quality.

\section{Introduction}

As key participants in the development of the spectatorship for recreational sport, international sports organisations are undoubtedly among the most important members of the recreational sport industry which has become a large-scale business. The Le Mans 24 hour race, Wimbledon and the Football World Cup are examples of international sports events.

The 24 Hours of Le Mans: It is considered that $3 \mathrm{~S}$ to mark the world's best automobile race, the 24 Hours of Le Mans, are Skill, Speed and Stamina. This race, organized by the Automobile Club de L'Ouest, associates the past and the present of the automotive world. The competition is organized on a non-permanent track at Circuit de la Sarthe in proximity of the Le Mans City by the Sarthe River. About 46 cars join the race, from different series of classes that include prototype high-performance vehicles, dedicated race cars and street cars.

Wimbledon: As a most creditable tennis event in the world, Wimbledon owes its prestige largely to its setting and the surrounding pomp. Competitions take place on a natural turf (grass) surface which makes this event unique. Wimbledon has shaped the history of tennis significantly; and contributed to its development as an egalitarian and highly skilled sport followed by millions. Wimbledon was originally invented in France in the 12th century; and it was modernized in Britain along 1800s.

World Cup Soccer: Although this tournament includes only 32 nations, billions of people around the world watch on the TV for a month every four years to witness who will claim the title of World Cup soccer champion. The teams included in the World Cup finals are the ones emerged as a result of a series of qualifying rounds played along the three preceding years. Accordingly, this 'tournament of tournaments' displays the finest teams from all around the world (National Geographic Top 10 Sporting Events, 2016).

Such major sporting events comprise one

1 - Anadolu University, Faculty of Sport Sciences, Department of Recreation. Eskisehir-TURKEY. 
of the most exciting and fast-growing sources of economic activity and tourism in many countries. International sports organisations are associated with important economic and social benefits. Their presence can promote the growth of extensive media presence that gradually widens across the city or region where events are held. International sports organisations only need to be set up once, but after being founded they generally make either significant positive or negative contributions to the host community in the long term (Crompton et al., 2001; Mihalik and Simonette, 1998; Ritchi and Aitken, 1985; Simsek, 2012). Kim et al. (2006) identified seven factors of international sports organizations: benefits of cultural exchange, economic benefits, natural resource and cultural development, social problems, traffic congestion and pollution, price increases and construction costs. In terms of their positive effects, international sports organisations can add to many areas of country's growth. They can promote the creation of new sectors and geographical areas of work, thus contributing economically to a host country. They can also enable greater tourist mobility and a better infrastructure. In addition, they can assure a healthier future for the population through sporting activities and the construction of more modern sports facilities. This may help develop a more success-oriented young population and create an overall healthier environment. Thus, all international sports organisations have a vitally important role in terms of the development and success of countries' recreational activities and sport industries (Simsek, 2011; Simsek, 2012).

Sports activities with many spectators constitute a quickly expanding competitive industry. However, many sports organisations also have to face the resistance of customers due to increasing prices for events and expectations concerning their quality (Howard and Crompton, 2004). Sports organisations in the United States of America experience this in large sport leagues (National Football League, Major League Baseball, National Basketball Association and National Hockey League), even though they strive to provide the best possible product and customer service as well as reduce operational costs. In this kind of a business environment, finding the opportunity to offer high-quality activities and services has become a critical objective for professional sports organisations.

Service providers rendering a highquality service for their consumers not only make a high profit, but also obtain customer loyalty, satisfaction and encouragement, which is observed in the entire service sector (Anderson et al., 1994; Anderson and Sullivan, 1993; Dagger and Sweeney, 2007; Fornell, 1992). In this context, Martinez et al. (2010) determined that one of the most important problems being faced by modern sport marketeers was the service quality providing the following arguments:

- the proxy measure of management performance;

- an important factor in positioning the company; and

- an essential determinant of customer behaviour variables such as customer loyalty.

It could be stated that customers have developed a general impression regarding some dimensions in the context of sport activities with many spectators, which are as follows:

- Game performance (Greenstein and Marcum, 1981; Hansen and Gauthier, 1989; Shofield, 1983),

- Facilities, additional services (Hansen and Gauthier, 1989),

- Event personnel, volunteers and service distribution systems (Getz, 2005).

Event quality was examined by researchers in terms of both marketing (Dale et al., 2005; Kelley and Turley, 2001; Shilbury, 1994; Wakefield et al., 1996) and operation (Getz et al., 2001). All these general impressions concerning the consumption experience determine the perceptions of the event quality. Getz (2005) emphasises the necessity for conceptualising the quality of sport activities as a mixture of various programmes and service presentation processes. The quality is affected by the competition, an atmosphere created by the facility, other consumers and other services being sold during the event in presentation of services in the recreational and sport area (Kelley and Turley, 2001). Since recreational and sport organisations aim to constantly provide a high-quality service (Tsitskari et al., 2006), the procurement of a quality experience that meets the expectations of consumers will support both the participation in future recreational and sport activities and the 
consumption of these activities (Tsuji et al., 2007). Since the quality of recreational and sport services is considered a factor determining the development of the organisation, the dimensions of the service quality become important in terms of analysing the quality and developing the accuracy and efficiency of the service (Perez et al., 2010).

More studies are required in order to set a valid and reliable service quality model in spectator sports. A sport industry aimed at spectators is an industry that has a great social and economic effect upon the international area, especially in Europe (Theodorakis and Alexandris, 2008). Table 1 shows the service quality models in spectator sports, as well as the dimensions, item numbers, usage areas of these models and the researchers investigating these issues.

There is still a limited number of studies aimed at measuring the service quality in spectator sports. Particular attention is paid to the difference of sports based on participation and aimed at spectators by the nature of the customers' role (active or passive) (Theodorakis and Alexandris, 2008). Some interventions have been made in spectator sports in order to measure the service quality (Ko et al., 2011; Theodorakis et al., 2011). Ko et al. (2011) developed the "Model of Event Quality for Spectator Sport" (MEQSS) and the "Scale of Event Quality for Spectator Sport" (SEQSS), which were specifically designed to evaluate the quality perceptions of spectators concerning the event. A method that has never been published in the service marketing literature is used in the development stage of this broad model. The scale (SEQSS) that is used with the model in this study is valid and reliable in evaluating the event quality in spectator sports. The SEQSS was developed to test the suggested conceptual model, i.e. the MEQSS. The SEQSS was designed by Nunnally and Bernstein according to the suggested scale development procedure. The majority of items that were involved in each lower dimension were adapted from previous studies. The hierarchical model of service quality for the sport industry that was previously used by Ko and Pastore (2005) is the primary resource guiding in the development of the model (MEQSS) that was suggested in this study and the scale (SEQSS) accompanying this model. The MEQSS and SEQSS involve 4 new lower dimensions. These dimensions, which were not included in the studies of Ko and Pastore (2004, 2005), are considered important in measuring the event quality of spectator sports. The scale being used involves 38 items. The service quality includes 5 dimensions and each lower dimension consists of 3 or 5 items and is evaluated with 12 lower dimensions. These dimensions are game/event quality (although when referring to track and field, we decided to use the term event quality), service quality of additional (subsidiary) events, interaction quality, outcome quality and physical environment quality.

\section{Material and Methods}

This research determined the effect of the quality perception of the World Indoor Athletics Championships perceived by the spectators. The hypotheses of the research were as follows:

$\mathrm{H}_{1}$ : The dimensions that made up the perception of the event quality of the World Indoor Athletics Championships differed depending on the demographic features of the sample group.

$\mathrm{H}_{2}$ : The demographic features of the sample group had an effect upon the dimensions that made up the perception of the event quality of the World Indoor Athletics Championships.

\section{Participants}

The study population consisted of spectators of the World Indoor Athletics Championships, İstanbul 2012. A total of 568 spectators (316 men (55.6\%) and 252 women $(44.4 \%))$ were selected from the determined population with a convenience sampling method. It might be very difficult to statistically generalise the results of a study, which is conducted based on samples determined with a non-random sampling method. However, in cases where it is impossible to reach the elements within the universe or the random selection of participants is not easy, just like in this study, the convenience sampling method is used to make some predictions about the present condition in the light of information, which has been obtained based on a certain sample though not statistically random. Furthermore, the convenience sampling method is defined as the shortest way of obtaining data in a rapid and inexpensive way 
(Nakip, 2003).

\section{Measures}

The scale of event quality for spectator sports (SEQSS) developed by Ko et al. (2011) was used to collect the study data. The scale consists of 5 dimensions and 12 lower dimensions, including event quality (skill performance, operating time, information), augmented service quality (entertainment, concessions), interaction quality (employee interaction, fan interaction), outcome quality (sociability, valence) and physical environment quality (ambience, design, signage). The scale, which determines the quality perception of an event, consists of a total of 38 items. In order to adapt the scale into Turkish, the following tests were performed: content validity (two linguists and expert opinions), convergent validity (lowest factor load value 0.426 , highest 0.773 ), desintegration/external validity (a positive moderate and high level relation in all factors) and construct validity (5 factors and 34 items). Then, following analyses were performed: a testretest reliability for determining the time invariance feature of the scale concerning the scale reliability (a linearly strong relationship), Cronbach Alpha (0.898) for the consistency and Item Total Correlation (item values in the range of 0.39 and 0.80). Additionally, confirmatory factor analysis was used to examine the accuracy of the five-dimension structure that was determined as a result of the explanatory factor analysis. Fit index results were determined as $\chi 2=451.86$; $\mathrm{df}=152$; $\chi 2 / \mathrm{df}=2.97 ; \mathrm{RMSEA}=0.064 ; \mathrm{CFI}=0.91 ; \mathrm{GFI}=$ 0.92; and AGFI $=0.88$. Figure 1 shows the dimensions, lower dimensions and item numbers of the SEQSS.

As seen in Table 1, the five-dimension original scale involves 34 items written in sentences. Items in the scale are ranked in the Five Point Likert form as follows: (1) Strongly Disagree, (2) Disagree, (3) Slightly Agree, (4) Agree, and (5) Strongly Agree. According to the acquired data, it was observed that the SEQSS provided the validity and reliability in the Turkish language and culture.

Procedures

This study used a general screening model along with descriptive statistics. The screening model is defined as a research approach that aims to describe a present condition as it is (Karasar, 2005; Ozmen, 2000).

\section{Statistical Analysis}

A t-test and one-way analysis of variance were used to examine the differences of the sample group according to gender, the educational level, age, occupation and a household income level in determining the quality perception of the World Indoor Athletics Championships. One of the prerequisites of variance analyses is that each group is randomly selected from a universe displaying a normal distribution. Considering this condition, it was determined that the acquired data were between the values of kurtosis (-0.11 and -1.23) and skewness (-0.23 and -0.74) and displayed a normal distribution. Variance homogeneity evaluation was performed with the Levene's test for averages differing in the t-test and one-way variance analysis, and all the data were determined to be homogeneous. In order to indicate the group causing the difference in gender, the educational level, occupation, age and a household income level, the measurement values providing the variance homogeneity were evaluated with Tukey's post-hoc tests $(p<0.05)$.

\section{Results}

Results of the analyses revealed that spectators evaluated the quality of the World Indoor Athletics Championships differently according to gender, the educational level, occupation, age and a household income level. Comparisons were made based on the groups with the highest average in tables, which were formed according to gender, the educational level, occupation, age and a household income level of the sample group. Table 2 shows the differentiation of the dimensions constituting the Quality Perception of an Event scale according to gender, the educational level and age of the sample group.

As a result of the t-test, the dimensions of event quality $(\mathrm{t}=2.84 ; p=.03)$, augmented service quality $(\mathrm{t}=3.54 ; p=.01)$ and physical environment quality $(\mathrm{t}=2.97 ; p=.03)$ concerning the event quality of the World Indoor Athletics Championships showed a significant difference according to gender. Views of women concerning the performance quality of the World Indoor Athletics Championships were found to be more positive than these of men $(\bar{X}=3.93$ and $\bar{X}=3.17$, respectively). Views of men concerning the 
augmented service quality of the event were more positive than these of women $(\bar{X}=3.11$ and $\bar{X}=$ 2.14 , respectively). A men's perception concerning the environmental features of the event was more positive than this of women $(\bar{X}=4.05$ and $\bar{X}=$ 3.21 , respectively). No significant difference was observed in the dimensions of interaction quality and outcome quality by gender.

According to the results of the one-way analysis of variance, a statistically significant difference was found in the dimensions of event quality $(\mathrm{F}=4.32 ; p=.01)$, augmented service quality $(\mathrm{F}=4.65 ; p=.01)$, interaction quality $(\mathrm{F}=$ 5.62; $p=.01)$ and the environment $(\mathrm{F}=2.62 ; p=$ $.08)$.

According to the results of the Tukey's test that was performed to determine between which groups the difference concerning educational levels was observed, the views of those with a level of primary education $(\bar{X}=4.34)$ and associate degree/undergraduate $(\bar{X}=4.49)$ were more positive than the views of those with a level of high school and its equivalents $(\bar{X}=3.47)$ as well as postgraduates $(\bar{X}=3.47)$. It was found that the views concerning the dimension of augmented service quality in the event quality of those with a level of high school and its equivalents $(\bar{X}=4.44), \quad$ associate degree/undergraduate $(\bar{X}=4.33)$ and postgraduate $(\bar{X}=4.58)$ were more positive than of those with a level of primary education $(\bar{X}=$ 3.51). The views concerning the dimension of interaction quality in the event quality of those with a level of primary education $(\bar{X}=4.32)$, high school and its equivalents $(\bar{X}=4.56)$ and associate degree/undergraduate $(\bar{X}=4.39)$ were found to be more positive than of postgraduates $(\bar{X}=3.72)$. The results also revealed that the views concerning the dimension of physical environment quality of those with a level of primary education $(\bar{X}=4.10)$, associate degree/undergraduate $(\bar{X}=4.70)$ and postgraduate $(\bar{X}=4.50)$ were more positive than of those with a level of high school and its equivalents $(\bar{X}=3.99)$. No significant differences were observed in the dimension of outcome quality concerning the event quality according to the educational level.

The results of the one-way analysis of variance indicated that the dimensions of augmented service quality $(\mathrm{F}=3.56 ; p=.01)$, interaction quality $(\mathrm{F}=3.32 ; p=.01)$ and physical environment quality $(\mathrm{F}=1.88 ; p=.02)$ differed significantly according to gender.

Following the results of the Tukey's test performed to determine which groups differed according to age, the views concerning the dimension of augmented service quality of those aged 26-35 ( $\bar{X}=2.92), 36-45(\bar{X}=2.83)$ and $46-55$ $(\bar{X}=2.87)$ were found to be more negative than of those aged $16-25(\bar{X}=3.24)$. With regard to the dimension of interaction quality, the views of those aged 16-25 ( $\bar{X}=3.02), 36-45(\bar{X}=3.72)$ and $46-55(\bar{X}=3.79)$ were more positive than of those aged 26-35 $(\bar{X}=2.89)$. The views concerning the dimension of physical environment quality of those aged $36-45(\bar{X}=4.21)$ were more positive than of those aged 16-25 ( $\bar{X}=3.52), 26-35(\bar{X}=$ 3.62) and 46-55 ( $\bar{X}=3.55)$. No significant difference was found in the dimension of event quality and results concerning the educational level.

Results of the one-way analysis of varianceindicated a statistically significant difference in the dimensions of event quality $(\mathrm{F}=$ $3.40 ; p=.01)$, outcome quality $(\mathrm{F}=1.35 ; p=.03)$ and physical environment quality $(\mathrm{F}=4.12 ; p=$ .01) considering the occupation variable.

According to the results of the Tukey's test performed to determine group differences considering the occupation variable, the views concerning the dimension of physical environment quality of students $(\bar{X}=4.43)$ were more positive than these of housewives $(\bar{X}=3.32)$, workers $(\bar{X}=3.39)$, officers $(\bar{X}=3.48)$, craftsmen $(\bar{X}=3.38)$, freelancers $(\bar{X}=3.97)$ and managers $(\bar{X}=3.50)$. It was found that the views concerning the dimension of outcome quality of housewives $(\bar{X}=4.03)$, craftsmen $(\bar{X}=4.59)$, freelancers $(\bar{X}=$ 3.71) and managers $(\bar{X}=3.50)$ were more positive than these of workers $(\bar{X}=3.39)$, officers $(\bar{X}=3.48)$ and students $(\bar{X}=4.43)$. With regard to the dimension of physical environment quality, the views of workers $(\bar{X}=3.39)$, officers $(\bar{X}=3.48)$, students $(\bar{X}=4.43)$, craftsmen $(\bar{X}=4.59)$ and managers $(\bar{X}=3.50)$ were found to be more positive than these of housewives $(\bar{X}=4.03)$ and freelancers $(\bar{X}=3.71)$.

The results of one-way analysis of variance indicated that the quality $(\mathrm{F}=2.44 ; p=$ $.012)$ and interaction quality $(\mathrm{F}=1.34 ; p=.03)$ 
dimensions differed significantly considering a household income level.

According to the results of the Tukey's test performed to observe group differences taking into account a household income level, the views of those with an income level of 4,000 TL and above $(\bar{X}=4,05)$ were more positive than of those with an income level of $1,000 \mathrm{TL}$ and below $(\bar{X}=3.28), 1,001-2,000$ TL $(\bar{X}=3.62), 2,001-3,000$ TL $(\bar{X}=3.43)$ and $3,001-4,000$ TL $(\bar{X}=3.32)$.

With regard to the dimension of interaction quality, it was found that the views of those with an income level of 1,001-2,000 TL $(\bar{X}=$ 3.91) were more positive than of those with an income level of $1,000 \mathrm{TL}$ and below $(\bar{X}=3.28)$, 2,001-3,000 TL ( $\bar{X}=3.80)$ and 4,000 TL and above $(\bar{X}=3.73)$. No significant differences were observed in the dimensions of augmented service quality, outcome quality and physical environment quality considering the household income level variable.

According to the results of the performed analyses:

$\mathrm{H} 1$ : it was found that the dimensions that made up the perception of the event quality of the World Indoor Athletics Championships differed depending on the demographic features of the sample group.

$\mathrm{H} 2$ : The results indicated that the demographic features of the sample group had an effect upon the dimensions that made up the perception of the event quality of the World Indoor Athletics Championships.

Table 1

Service Quality Scales in Spectator Sports

\begin{tabular}{|c|c|c|c|c|c|}
\hline Researcher & Scales & $\begin{array}{c}\text { Item } \\
\text { Number }\end{array}$ & $\begin{array}{l}\text { Dimension } \\
\text { Number }\end{array}$ & Dimension Name & Area \\
\hline McDonald et al. (1995) & TEAMQUAL & - & 5 & $\begin{array}{l}\text { Reliability, Responsiveness, } \\
\text { Assurance, Empathy, Physical } \\
\text { properties }\end{array}$ & $\begin{array}{c}\text { Professional } \\
\text { Sport }\end{array}$ \\
\hline Wakefield et al. (1996) & SPORTSCAPE & 30 & 8 & $\begin{array}{l}\text { Parking lot, Esthetics, } \\
\text { Scoreboard, Comfort, Space } \\
\text { settlement, Functionality, Signs, } \\
\text { Staying at a facility }\end{array}$ & $\begin{array}{c}\text { Professional } \\
\text { Sport }\end{array}$ \\
\hline $\begin{array}{l}\text { Theodorakis et al. } \\
\qquad(2001)\end{array}$ & SPORTSERV & 20 & 5 & $\begin{array}{l}\text { Access, Reliability, Eagerness, } \\
\text { Concrete properties, Security }\end{array}$ & $\begin{array}{c}\text { Professional } \\
\text { Sport }\end{array}$ \\
\hline $\begin{array}{l}\text { Kelley and Turley } \\
\qquad(2001)\end{array}$ & - & 35 & 9 & $\begin{array}{l}\text { Personnel, Price, Access to the } \\
\text { facility, Privilege, Comfort, } \\
\text { Match experience, Show, } \\
\text { Convenience, Smoking }\end{array}$ & $\begin{array}{l}\text { Professional } \\
\text { Sport }\end{array}$ \\
\hline $\begin{array}{l}\text { Westerbeek and } \\
\text { Shilbury (2003) }\end{array}$ & - & 16 & 3 & $\begin{array}{l}\text { Core sport product, Common } \\
\text { service production, } \\
\text { SPORTSCAPE property }\end{array}$ & $\begin{array}{c}\text { Professional } \\
\text { Sport }\end{array}$ \\
\hline Gencer (2005) & S_PSQPS & 20 & 3 & $\begin{array}{l}\text { Interaction quality, Physical } \\
\text { environment quality, Core } \\
\text { service quality }\end{array}$ & $\begin{array}{c}\text { Professional } \\
\text { Sport }\end{array}$ \\
\hline \multirow{2}{*}{$\begin{array}{l}\text { Kuenzel and Yassim } \\
\qquad(2007) \\
\text { Ko et al. (2011) }\end{array}$} & - & 10 & 3 & $\begin{array}{l}\text { Social interaction, Event quality, } \\
\text { Ambience }\end{array}$ & $\begin{array}{c}\text { Professional } \\
\text { Sport }\end{array}$ \\
\hline & $\begin{array}{l}\text { SEQSS } \\
\text { MEQSS }\end{array}$ & 40 & 5 & $\begin{array}{l}\text { Game quality, Service quality of } \\
\text { additional (subsidiary) events, } \\
\text { Interaction quality, Result } \\
\text { quality, Physical environment } \\
\text { quality }\end{array}$ & $\begin{array}{c}\text { Professional } \\
\text { Sport }\end{array}$ \\
\hline
\end{tabular}

Resource: (Ko et al., 2011; Theodorakis and Alexandris, 2008; Yildiz, 2012) 
Table 2

Differentiation of Quality Perception Dimensions of the Event According to Gender, the Educational Level and Age of the Sample Group

\begin{tabular}{|c|c|c|c|c|c|c|}
\hline DIMENSIONS & GENDER & $\mathrm{n}$ & $\bar{x}$ & Sd. & $t$ & $p$ \\
\hline \multirow[t]{2}{*}{ Event quality } & Male & 347 & 3.17 & .82 & 2.84 & $.03^{*}$ \\
\hline & Female & 221 & 3.93 & .85 & & \\
\hline \multirow{3}{*}{$\begin{array}{l}\text { Augmented } \\
\text { service quality }\end{array}$} & Male & 347 & 3.11 & .74 & 3.54 & $.01^{* *}$ \\
\hline & Female & 221 & 2.14 & .80 & & \\
\hline & Female & 221 & 3.75 & .75 & & \\
\hline \multirow{2}{*}{$\begin{array}{l}\text { Physical } \\
\text { environment } \\
\text { quality }\end{array}$} & Male & 347 & 4.05 & .84 & 2.97 & $.03^{* *}$ \\
\hline & Female & 221 & 3.21 & .77 & & \\
\hline \multirow[t]{3}{*}{ DIMENSIONS } & EDUCATIONAL LEVEL & $\mathrm{n}$ & $\bar{x}$ & Sd. & $\mathrm{F}$ & $p$ \\
\hline & Primary Education & 52 & 4.34 & .82 & 4.32 & $.01^{* *}$ \\
\hline & High Schools and Their Equivalents & 148 & 3.47 & .75 & & \\
\hline \multirow[t]{3}{*}{ Event quality } & Associate Degree/Undergraduate & 332 & 4.46 & .88 & & \\
\hline & Postgraduate & 36 & 3.47 & .75 & & \\
\hline & Primary Education & 52 & 3.51 & .77 & 4.65 & $.01^{* *}$ \\
\hline \multirow{4}{*}{$\begin{array}{l}\text { Augmented } \\
\text { service quality }\end{array}$} & High Schools and Their Equivalents & 148 & 4.44 & .74 & & \\
\hline & Associate Degree/Undergraduate & 332 & 4.33 & .76 & & \\
\hline & Postgraduate & 36 & 4.58 & .80 & & \\
\hline & Primary Education & 52 & 4.32 & .91 & 5.62 & $.01^{* *}$ \\
\hline \multirow[t]{3}{*}{ Interaction quality } & High Schools and Their Equivalents & 148 & 4.56 & .70 & & \\
\hline & Associate Degree/Undergraduate & 332 & 4.39 & .80 & & \\
\hline & Postgraduate & 36 & 3.72 & .68 & & \\
\hline \multirow{4}{*}{$\begin{array}{l}\text { Physical } \\
\text { Environment } \\
\text { quality }\end{array}$} & Primary Education & 52 & 4.10 & .82 & & \\
\hline & High Schools and Their Equivalents & 148 & 3.99 & .72 & 262 & $08^{* *}$ \\
\hline & Associate Degree/Undergraduate & 332 & 4.70 & .89 & 2.02 & .00 \\
\hline & Postgraduate & 36 & 4.50 & .68 & & \\
\hline DIMENSIONS & AGE & $\mathrm{n}$ & $\bar{x}$ & Sd. & F & $p$ \\
\hline \multirow{6}{*}{$\begin{array}{l}\text { Augmented } \\
\text { service quality }\end{array}$} & Between 16-25 & 84 & 3.45 & .84 & 3.56 & $.01^{* *}$ \\
\hline & Between 26-35 & 248 & 2.92 & .69 & & \\
\hline & Between 36-45 & 139 & 2.83 & .76 & & \\
\hline & Between 46-55 & 97 & 2.87 & .80 & & \\
\hline & Between 16-25 & 84 & 3.02 & .75 & 3.32 & $.01^{* *}$ \\
\hline & Between 26-35 & 248 & 2.89 & .76 & & \\
\hline \multirow[t]{3}{*}{ Interaction quality } & Between 36-45 & 139 & 3.72 & .72 & & \\
\hline & Between 46-55 & 97 & 3.79 & .79 & & \\
\hline & Between 16-25 & 84 & 3.52 & .79 & 1.88 & $.02^{*}$ \\
\hline \multirow{3}{*}{$\begin{array}{l}\text { Physical } \\
\text { environment } \\
\text { quality }\end{array}$} & Between 26-35 & 248 & 3.62 & .71 & & \\
\hline & Between 36-45 & 139 & 4.21 & .78 & & \\
\hline & Between 46-55 & 97 & 3.55 & .77 & & \\
\hline
\end{tabular}


Table 3

Differentiation of Quality Perception Dimensions of the Event According to the Occupation and Household Income Level of the Sample Group

\begin{tabular}{|c|c|c|c|c|c|c|}
\hline DIMENSIONS & OCCUPATION & $n$ & $\bar{x}$ & Sd. & $\mathrm{F}$ & $p$ \\
\hline \multirow{6}{*}{ Event quality } & Housewife & 8 & 3.32 & .69 & 3.40 & $.01^{* *}$ \\
\hline & Worker & 40 & 3.39 & .81 & & \\
\hline & Officer & 160 & 3.48 & .87 & & \\
\hline & Student & 80 & 4.43 & .74 & & \\
\hline & Craftsman & 144 & 3.38 & .86 & & \\
\hline & Freelancer & 83 & 3.46 & .88 & & \\
\hline \multirow{9}{*}{ Outcome quality } & Manager & 53 & 3.50 & .80 & & \\
\hline & Housewife & 8 & 3.74 & .59 & & \\
\hline & Worker & 40 & 4.24 & .76 & & \\
\hline & Officer & 160 & 4.16 & .77 & & \\
\hline & Student & 80 & 4.16 & .82 & 1.35 & $.03^{*}$ \\
\hline & Craftsman & 144 & 3.93 & .79 & & \\
\hline & Freelancer & 83 & 3.99 & .72 & & \\
\hline & Manager & 53 & 3.96 & .71 & & \\
\hline & Housewife & 8 & 3.39 & .92 & & \\
\hline \multirow{5}{*}{$\begin{array}{l}\text { Physical } \\
\text { environment } \\
\text { quality }\end{array}$} & Worker & 40 & 4.47 & .79 & & \\
\hline & Officer & 160 & 4.19 & .88 & & \\
\hline & Student & 80 & 4.25 & .71 & 4.12 & $.01^{* *}$ \\
\hline & Craftsman & 144 & 4.28 & .87 & & \\
\hline & Freelancer & 83 & 3.65 & .90 & & \\
\hline \multirow[b]{2}{*}{ DIMENSION } & Manager & 53 & 4.47 & .89 & & \\
\hline & $\begin{array}{c}\text { HOUSEHOLD INCOME } \\
\text { LEVEL }\end{array}$ & $\mathrm{n}$ & $\bar{x}$ & Sd. & $\mathrm{F}$ & $p$ \\
\hline \multirow{5}{*}{ Interaction quality } & $1,000 \mathrm{TL}$ and below & 62 & 3.48 & .91 & 2.74 & $.01^{* *}$ \\
\hline & $1,001-2,000 \mathrm{TL}$ & 186 & 3.91 & .73 & & \\
\hline & $2,001-3,000 \mathrm{TL}$ & 139 & 4.20 & .74 & & \\
\hline & $3,001-4,000 \mathrm{TL}$ & 80 & 4.53 & .86 & & \\
\hline & 4,001 TL and above & 101 & 4.23 & .74 & & \\
\hline \multirow{5}{*}{$\begin{array}{l}\text { Physical } \\
\text { environment } \\
\text { quality }\end{array}$} & $1,000 \mathrm{TL}$ and below & 62 & 3.56 & .85 & & \\
\hline & $1,001-2,000 \mathrm{TL}$ & 186 & 3.78 & .81 & & \\
\hline & $2,001-3,000 \mathrm{TL}$ & 139 & 4.36 & .86 & 3.20 & $.01^{* *}$ \\
\hline & $3,001-4,000 \mathrm{TL}$ & 80 & 4.15 & .86 & & \\
\hline & $4,001 \mathrm{TL}$ and above & 101 & 4.58 & .90 & & \\
\hline
\end{tabular}

(1=Strongly Disagree, $5=$ Strongly Agree) 


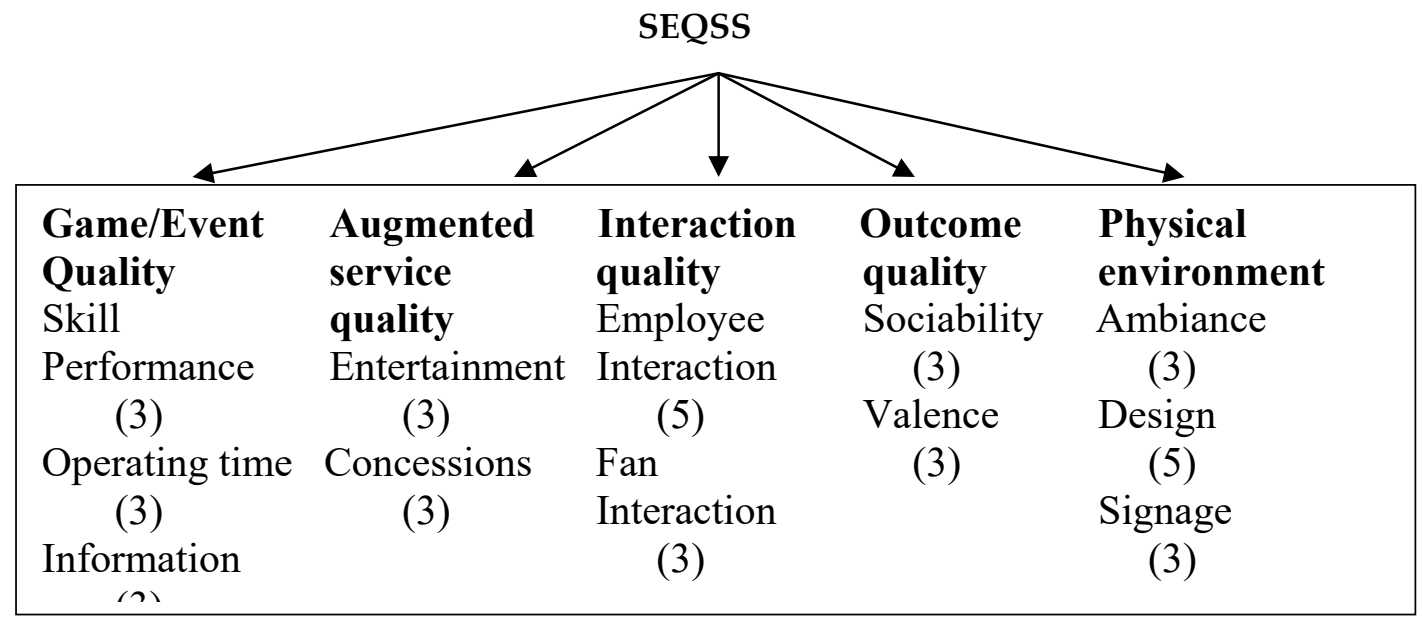

Figure 1

Dimensions, Lower Dimensions and Item Numbers of the scale of event quality for spectator sports (SEQSS)

\section{Discussion}

Upon analyzing the literature concerning service quality, the researchers apparently agree that this concept is both multidimensional and hierarchical. Researchers have formed unique service quality dimensions in generating special scales in the sport and recreation industry. Even though each instrument and scale are unique, there are some repeated topics and similarities in studies on this industry due to the variety of service quality that is required to be measured and its dimensions. More studies are required in order to set a valid and reliable service quality model in spectator sports. A sport industry aimed at spectators is an industry that has a great social and economic effect in Europe (Theodorakis and Alexandris, 2008).

Considering the study findings obtained according to gender of the sample group, it was found that the sample group displayed significant differences in the dimensions of event quality, augmented service quality and physical environment quality constituting the event quality. While women paid attention to performance quality of the events of the 2012 World Indoor Athletics Championships, men attached greater importance to the dimensions of augmented service quality and physical environment quality. Brady et al. (2006) and Tsuji et al. (2007) state that the satisfaction levels of spectators resulting from the performance quality are affected by the basic services being provided in events. According to some findings, Mikulic and Prebezac (2011) indicate that male spectators attach greater importance to the facility and equipment quality than female spectators. In opposition to the study of Mikulic and Prebezac (2011), Theodorakis et al. (2004) indicate that women have higher levels of service expectations than men do. The aformentioned studies attract attention to the differences concerning the expectations and satisfaction with regard to the service quality according to gender. In this context, it is required to deeply investigate the differences of the service quality in spectator sports considering gender.

According to the study findings with respect to the educational level of the sample group, a high average was determined in those with a level of postgraduate education concerning the event and interaction quality of the events of the 2012 World Indoor Athletics Championships, as well as in those with a level of high school and its equivalents concerning the physical environment quality and those with a level of primary education concerning the augmented service quality. Chow et al. (2007) stated that people with a higher educational level had higher expectations of the service quality. Similar findings were also observed in the present study. While those with an educational level of high 
school and its equivalents had a high average in the interaction quality dimension of the interaction quality, the sample group differing in the dimensions of event quality, augmented service quality and physical environment quality had an educational level of undergraduate and postgraduate. Those with an educational level of associate degree/undergraduate had the highest average in the dimension of physical environment quality in the events of the 2012 World Indoor Athletics Championships. Ko and Pastore (2005) asserted that the most important dimension in the evaluation of service quality was the dimension of physical environment quality. The researchers suggested innovative design and style approaches to develop the atmosphere of facilities. Physical environment quality may affect the cognitive/emotional states and buying behaviours of customers (Donovan and Rossiter, 1982; Wakefield et al., 1996), as the majority of services utilised by consumers within the physical facility are produced and consumed all at the same time (Bitner, 1992). It was stated that the event service experiences of customers focused on sports facilities during the sport and recreational services (Westerbeek, 2000). In this context, it could be suggested that high expectations of the events of the 2012 World Indoor Athletics Championships were met according to the educational level of the sample group.

Examining the study findings obtained according to the occupations of the sample group, a significant difference was displayed by workers who had a high average in the dimension of physical environment quality and by students who had a high average in the dimensions of event quality and augmented service quality. Each individual may have different judgments concerning quality (Aslan and Koçak, 2011). Understanding the differences between individuals enables the organisations to develop and design better strategies concerning the service quality aimed at occupational groups (Landrum et al., 2010). In the study of Ko and Pastore (2007) in which $82 \%$ of the sample group consisted of students, and which concentrated on the service quality as well as customer satisfaction of campus recreation programmes, it was determined that participants had a high average concerning the general service quality. The authors of that study stated that while the dimension of result had the highest average, the dimension of physical environment quality had the lowest average. The high average of students concerning the outcome quality in the present study findings regarding the occupational groups corresponds to the result of Ko and Pastore (2007). The fourth dimension of event quality is the outcome quality. This dimension focuses on the result of service and shows the concept of quality (Ko and Pastore, 2005). Gröngroos (1984) stated that the consumer obtains the outcome quality as a result of his/her interaction with the company providing the service. Spectators who witness sporting activities generally expect social and psychological benefits such as excitement, joy and social interaction (Milne and McDonald, 1999). The level of these acquired benefits affects the perceptions of sport spectators with regard to the outcome quality, which is fairly supported by the study results.

Analyzing the study findings obtained according to the household income levels of the sample group, a significant difference was displayed by those who had a household income level of 3,001 and 4,000 TL and a high average in the dimension of interaction, and by those who had a household income level of 4,001 TL and above and a high average in the dimension of physical environment quality, compared to other groups. The fact that those aged $46-55$ had a high average in the dimension of augmented service quality revealed that the expectations of the events of the 2012 World Indoor Athletics Championships were met in terms of this dimension. Age is asserted to be a strong determinant of the customer behaviour affecting elements such as interest, taste, buying behaviour, political preference and investment (Lim et al., 2008). Callan and Bowman (2000) stated that adults (55 and older) comprised a smart group with high expectations from hotel services and attached importance to the service rather than the real price and price cut.

The findings of the present study, with respect to the household income levels of the sample group, indicated a significant difference in terms of those who had a household income level of 3,001 and 4,000 TL and a high average in the dimension of interaction, and those who had a household income level of 4,001 TL and above and a high average in the dimension of physical environment quality, compared to other groups. 
Scott and Shieff (1993) stated that customers with different income levels had different service quality perceptions, which confirms the findings of this study. Lim et al. (2008) stated that individuals with a high income level generally had a high educational level as well. Regarding this condition, generally this kind of customers tend to question more in the process of knowledge acquisition before making a decision. Thus, customers with a high income level may perceive the service quality in a different way compared to those with a lower income level. Following the results of the present study, the fact that individuals with a high income level have higher averages in the dimensions of interaction quality and physical environment quality compared to other groups shows that individuals with a high income level perceive the service quality in a different way. Holton (2004) stated that customers with a high income level demanded to get service from expert and proactive service providers who would fulfil their needs. He also stated that individuals with a high income level sought quality in the service interaction, which shows a similarity with findings of the present study. In another study, Ko and Pastore (2005) stated that attitudes, behaviours and experiences of individual employees in events were effective upon the evaluations of consumers regarding the service quality. In addition, the interaction between consumers expresses the subjective perception of consumers who evaluate the attitudes and behaviours of other consumers during the fulfilment of service regarding how the service is provided. The quality perception of the consumer concerning service is affected by the attitudes and behaviours of other consumers. This social process is mentioned in the recreational and sport services, where consumers have a high rate of interaction (Ko and Pastore, 2005). The physical environment quality dimension of event quality refers to the facility where the service is provided. This dimension is considered among the most important dimensions in evaluating service quality. Many studies on service quality in the sport and recreational industry indicate the importance of the dimension of physical environment quality (Chelladurai and Chang, 2000; Howat et al., 2008; Kim and Kim, 1995; Ko and Pastore, 2005, 2007). The sample group of our study presented significant differences in the physical environment quality dimension considering all comparisons with the independent variables of gender, the educational level, occupation and a household income level. Thus, these results are in line with findings of other researchers emphasising the importance of the dimension of physical environment quality.

Implications

The findings of this study have important implications for managers and marketers of major spectator sports events. The scale can provide event managers with analytical tools for measurement of spectators' perceptions of event quality. More specifically, the five dimensions of the framework can be used ("game/event quality", "augmented service quality", "interaction quality", "physical environment quality" and "outcome quality") to identify potential problem areas in event operations and thus, provide guidance for future improvement of services. Understanding particular operational strengths and weaknesses is of crucial importance to managers who seek to increase spectator patronage through the provision of excellent onfield and off-field products and services.

\section{Limitations and Recommendations for Future $R$ esearch}

Several limitations of the study should be addressed. First of all, the data were collected from spectators of the 2012 World Indoor Athletics Championships which means that the results can be generalized only for similar events. The scale of event quality for spectator sports (SEQSS) is a new scale developed in 2011 which should be applied to different cultures and samples to obtain more reliable and valid data. Another limitation consists of 5 dimensions and 12 lower dimensions, including game/event quality (skill performance, operating time, information), augmented service quality (entertainment, concessions), interaction quality (employee interaction, fan interaction), outcome quality (sociability, valence) and physical environment quality (ambience, design, signage). According to the literature on the topic, other dimensions (i.e., safety, sport goods) which affect the quality of the service perception of events should be also considered and examined in more detail 


\section{Acknowledgments}

The author would like to thank the pollster for their collaboration and support.

\section{References}

Anderson EW, Fornell C, Lehmann DR. Customer satisfaction, market share, and profitability: findings from Sweden. J Marketing, 1994; 58(3): 53-66

Anderson EW, Sullivan M. The antecedents and consequences of customer satisfaction for firms. Market Sci, 1993; 12(2): 125-143

Aslan M, Koçak MS. Determination of the service quality among sport and fitness centers of the selected universities. International Journal of Hum Sciences, 2011; 8(2): 817-833

Bitner MJ. Servicescapes: the impact of physical surroundings on customers and employees. J Marketing, 1992; 56(2): 57-71

Brady MK, Voorhees CM, Cronin JJ, Bourdeau BL. The good guys don't always win: the effect of valence on service perceptions and consequences. Journal of Services Marketing, 2006; 20(2): 83-91

Callan RJ, Bowman L. Selecting a hotel and determining salient quality attributes: a preliminary study of mature British travellers. The International Journal of Tourism Research, 2000; 2(2): 97-118

Chelladurai P, Chang K. Targets And standards of quality in sport services. Sport Management Review, 2006; 3: $1-22$

Chow HI, Lau VP, Lo WT, Sha Z, Yun H. Service quality in restaurant operations in China: decision- and experiential-oriented perspectives. Hospitality Management, 2007; 26: 698-710

Crompton JL, Lee S, Shuster TS. A guide for undertaking economic impact studies: the Springfest example. Journal of Travel Research, 2001; 40: 79-87

Dagger TS, Sweeney JC. Service quality attribute weights: how do novice and longer-term customers construct service quality performance? Journal of Service Research, 2007; 10(1): 22-42

Dale B, Iwaarden JV, Wiele TVD, Williams R. Service improvements in a sports environment: a study of spectator attendance. Managing Service Quality, 2005; 15(5): 470-84

Donovan RJ, Rossiter JR. Store atmosphere: an environmental psychology approach. Journal of Retailing, 1982; 58: $34-57$

Fornell C. A national customer satisfaction barometer: the Swedish experience. J Marketing, 1992; 56(1): 6-21

Gencer TR, Demir C, Aycan A. Variables affecting sport tourists' service quality perceptions in ski resorts. Ege Academic Review, 2008; 8(2): 437-450

Getz D. Event Management and Event Tourism, 2nd ed. New York, NY: Cognizant Communication; 2005

Getz D, O'Neill M, Carlsen J. Service quality evaluation at events through service mapping. Journal of Travel Research, 2001; 39(2): 380-390

Greenstein TN, Marcum JP. Factors affecting attendance of major league baseball: team performance. Review of Sport and Leisure, 1981; 6(2): 21-34

Grögnroos C. A service quality model and its marketing implications. European Journal of Marketing, 1984; 18(4): 36-44

Hansen H, Gauthier R. Factors affecting attendance at professional sport events. J Sport Manage, 1989; 3(1): $15-32$

Holton L. The rich are different. ABA Journal, 2004; 85-90

Howard DR, Crompton JL. Financing Sport, 2nd ed., Fitness Information Technology, Morgantown, WV:. 
Fitness Information Technology; 2004

Howat G, Crilley G, McGrath R. A focused service quality, benefits, overall satisfaction and loyalty model for public aquatic centres. Managing Leisure, 2008; 13(3-4): 139-161

Karasar N. Scientific Research Methods. Ankara: Nobel Issues, 2005

Kelley SW, Turley LW. Consumer perceptions of service quality attributes at sporting events. Journal of Business Research, 2001; 54(2): 161-166

Kim D, Kim SY. QUESC: an instrument for assessing the service quality of sport centers in Korea. J Spor Manage, 1995; 9: 208-220

Kim HJ, Gursoy D, Lee SB. The impact of the 2002 World Cup on South Korea: comparisons of pre- and postgames. Tourism Manage, 2006; 27: 86-96.

Ko YJ, Pastore DL. Current issues and conceptualizations of service quality in the recreation sport industry. Sport Marketing Quarterly, 2004; 3(3): 158-166

Ko YJ, Pastore DL. A hierarchical model of service quality for the recreational sport industry. Sport Marketing Quarterly, 2005; 14: 84-97

Ko YJ, Pastore DL. An instrument to assess customer perception of service quality and satisfaction in campus recreation programs. Recreational Sports Journal, 2007; 31: 32-42

Ko JY, Zhang J, Cattani K, Pastore D. Assessment of event quality in major spectator sports. Managing Service Quality, 2011; 21(3): 304-322

Kuenzel S, Yassim M. The effect of joy on behaviour of bricket spectators: The mediating role of satisfaction. Managing Leisure, 2007; 12: 43-57

Landrum H, Prybutok VR, Zhang X. The moderating effect of occupation on the perception of information services quality and success. Computers $\mathcal{E}$ Industrial Engineering, 2010; 58: 133-142

Lim CG, Bennett RR, Dagger T. The impact of service contact type and demographic characteristics on service quality perceptions. Journal of Services Marketing, 2008; 22(7): 550-561

Martinez JA, Ko YJ, Martinez L. An application of fuzzy logic to service quality research: a case of fitness service. J Sport Manage, 2010; 24(5): 502-523

McDonald MA, Sutton WA, Milne GR. TEAMQUAL: Measuring service quality in professional sports. Sport Marketing Quarterly, 1995; 4(2): 9-15

Milne GR, McDonald MA. Motivation of sport Consumer" In Sport Marketing: Managing the exchange process. Sudbury, MA: Jones and Bartlett Publisher; 1999

Mihalik BJ, Simonette L. Resident perceptions of the 1996 Summer Olympic Games-Year II. Festival Management and Event Tourism, 1998; 5(1): 9-19

Mikulic J, Prebezac D. Evaluating hotel animation programs at Mediterranean sun-and-sea resorts: an impact-asymmetry analysis. Tourism Management, 2011; 32: 688-696

Nakip M. Techniques for Marketing Research and SPSS Supported Applications. Ankara: Seçkin Issues, 183; 2003

National Geographic Top 10 - Sporting Events. Available at: http://admin.wpf.test.nationalgeographic.com/travel/top-10/sporting-events/; acessed on 15.05.2016

Nunnally JC, Bernstein IH. Psychometric Theory. McGraw Hill, New York; 1994

Ozmen A. Applied Research Sampling Methods. Eskisehir, Turkey: Anadolu University Issues, 40; 2000

Perez VC, Minguet C, Freire MG. Sports Management services: The dimensions of quality. Journal of Human Sport \& Exercise, 2010; 5(11): 295-306

Ritchie JRB, Aitken CE. Assessing the impacts of the 1988 Olympic Winter Games: the research program and initial results. Journal of Travel Research, 1984; 22(3): 17-25

Scott D, Shieff D. Service quality components and group criteria in local government. International Journal of Service Industry Management, 1993; 4(4): 42-53 
Shilbury D. Delivering quality service in professional sport. Sport Marketing Quarterly, 1994; 3(1): 29-35

Shofield JA. Performance and attendance at professional team sports. Journal of Sport Behavior, 1983; 6(4): 196206

Simsek KY. Socio-cultural and economic impact of Erzurum Winter Universiade 2011 on Erzurum City. Selçuk Universty Journal of Sport Science, 2011; (13)3: 383-393

Simsek KY. Adaption of "mega event impact scale": validity and reliability study (2011 Erzurum 25. Winter Universiade). Pamukkale Journal of Sport Science, 2012; (3)2: 14-17

Theodorakis ND, Kambitsis C, Laios A, Koustelios A. Relationship between measure of service quality and satisfaction of spectator in professional sports. Managing Service Quality, 2001; 11(6): 431-438

Theodorakis ND, Alexandris K, Rodrigez P, Sarmento PJ. Measuring customer satisfaction in the contex of health clubs in Portugal. International Sports Journal, 2004; 8(1): 44-53

Theodorakis ND, Alexandris K. Can service quality predict spectators' behavioral intentions in professional football? Managing Leisure, 2008; 13: 162-178

Theodorakis ND, Alexandris K, Ko YJ. A Service quality framework in the context of professional football in greece. International Journal of Sport Marketing \& Sponsorship, 2011; 12(4): 337-351

Tsitskari E, Tsiotras D, Tsiotras G. Measuring service quality in sport services. Totaly Quality Management and Business Excellence, 2006; 17(5): 623-631

Tsuji Y, Bennett G, Zhang J. Consumer satisfaction with an action sports event. Sport Marketing Quarterly, 2007; 16(4): 199-208

Westerbeek HM. The influence of frequency of attendance and age on place-specific dimensions of service quality at Australian rules football matches. Sport Marketing Quarterly, 2000; 9(4): 194-202

Westerbeek HM, Shilbury D. A conceptual model for sport services marketing research: Integrating quality, value and catisfaction. International Journal of Sport Marketing \& Sponsorship, 2003; 5(1): 11-31

Yildiz SM. Instruments for measuring service quality in sport and physical activity services Collegium Antropologium, 2012; 2: 689-696

\section{Corresponding author:}

\section{Kerem Yildirim Simsek}

Anadolu University

Faculty of Sport Sciences

Department of Recreation

Eskisehir-TURKEY

Phone: +90 5316115424

E-mail: keremys@anadolu.edu.tr 